\title{
1 A Hotspot Atop: Rivers of the Guyana Highlands Hold High Diversity of Endemic Pencil 2 Catfish
}

4 Running Title: Trichomycterus of the Guyana highlands

6 Holden J. Paz ${ }^{1}$, Malorie M. Hayes ${ }^{1}$, Carla C. Stout ${ }^{1,2}$, David C. Werneke ${ }^{1}$, Jonathan W.

7 Armbruster ${ }^{1 *}$

8 1 Auburn University, Auburn, AL 36849; ${ }^{2}$ California State Polytechnic University, Pomona,

9 Pomona, CA 91768

$10 *$ Denotes corresponding author

\section{ACKNOWLEDGEMENTS}

13 This research was supported by an undergraduate Research Grant-In-Aid from the Department of

14 Biological Sciences, Auburn University to HJP and a grant from the COYPU Foundation to

15 JWA. JWA and DCW would like to thank Donald Taphorn, Nathan Lujan, and Elford Liverpool

16 as well as Aiesha Williams and Chuck Hutchinson of the Guyana WWF for arranging trips to

17 collect fishes in Guyana, and Ovid Williams for acting as a liaison to indigenous communities.

18 We would like to thank the Patamona people of Kaibarupai, Ayangana, and Chenapowu for

19 hosting us on expeditions and imparting their knowledge and skills in the field. Numerous people

20 aided in the collection of specimens, and we owe them our deepest gratitude. Special thanks to

21 Liz Ochoa for helping us design and implement this study. Thanks to Erling Holm for sending

22 specimens and tissues from ROM.

\section{ABSTRACT}

25 Aim

26 The Pakaraima Mountains are an ancient mountain range along the borders of Guyana, Brazil,

27 and Venezuela. The high plateau is drained by multiple river systems in all directions. Although

28 hypotheses have been presented for the biogeographic relationships of lowland rivers, the

29 interconnectivity of rivers on the top of the plateau is unknown. With multiple complex rivers in

30 a small, upland area we predicted a high level of endemism for stream fishes and complex

31 biogeographic relationships. We explore this with the incredibly diverse pencil catfish genus 
32 Trichomycterus. Only two species are known from the region. In this study, we 1) confirm the

33 discovery of multiple endemic Trichomycterus species in the region, 2) determine the

34 phylogenetic placement of our samples to posit biogeographical scenarios, and 3) provide

35 clarification for the identification of $T$. guianensis based on morphology.

\section{Location}

37 Pakaraima Mountains, a part of the Guiana Shield in Guyana, South America

\section{Taxon}

39 Pencil catfish genus Trichomycterus

\section{$40 \quad$ Methods}

41 Using collections from recent expeditions to the Pakaraima Mountains of Guyana, we amplified

42 three mitochondrial (16S, COI, and cytb) and two nuclear markers (myh6 and RAG2). We

43 constructed individual gene trees as well as a concatenated tree to determine the placement of

44 these taxa within the Trichomycterus of the Trans-andean/Amazonian clade.

\section{Results}

46 Our results identify six unique lineages in the highlands of Guyana. Only two species,

47 Trichomycterus guianensis and T. conradi, were previously known to science.

48 Main Conclusions

49 The Pakaraima Mountains of South America are a region of high endemism, as demonstrated

50 here in Trichomycterus catfishes. We find two species occupying multiple basins, suggesting that

51 Pakaraima streams either maintain or had some degree of recent connectivity. We identify six

52 endemic lineages of Trichomycterus from the highlands of the Pakaraima Mountains. The upper

53 portions of the study rivers have been connected either through surface flow or by stream

54 capture. Both processes have occurred on multiple time scales and are independent of the

55 patterns seen in the lowlands.

56 Keywords: catfish, fishes, freshwater, Guiana shield, neotropics, systematics, Trichomycterus,

\section{INTRODUCTION}

59 The Pakaraima Mountains run along the borders of Guyana, Brazil, and

60 Venezuela. These ancient mountains have been the subject of diverse lore of the

61 indigenous inhabitants of the region as well as the western world. Sir Arthur Conan

62 Doyle (1912), in The Lost World, imagined dinosaurs and other ancient organisms on the 
63 high plateau and Pixar Animation Studios, in the movie Up (Docter \& Peterson, 2009), imagined

64 a house perched on top of "Paradise Falls" and an undescribed, endemic species of flightless

65 bird. The artists that designed Paradise Falls recognized that many of the rivers of the region fall

66 off of the escarpment in dramatic waterfalls such as Kaieteur, Amaila, and Orinduik Falls.

Although dinosaurs and large, flightless birds do not appear to be denizens of the

68 Pakaraimas, the streams there hold a high degree of endemism (Alofs, Liverpool, Taphorn, \&

69 Bernard, 2014; Armbruster \& Taphorn, 2011; Hardman, Page, Sabaj, Armbruster, \& Knouft,

70 2002). The Pakaraimas (Figure 1) are drained to the north by the Mazaruni and Cuyuni rivers, to

71 the east by the Potaro River (Essequibo River drainage), to the southwest by the Ireng and

72 Uraricoera rivers (Amazon River drainage), and to the west and northwest by the Caroni River

73 (Orinoco River drainage). The mountains are the remains of Archaean and Proterozoic rocks

74 whose lighter sediments have eroded to fill formerly lacustrine basins such as the Venezuelan

75 Llanos and the Rupununi Savanna of Guyana (see Lujan \& Armbruster, 2011, for review). This

76 erosion has left behind a durable core that often has steep faces that the rivers run off of in

77 spectacular waterfalls. Below the falls, the rivers often have some rapids complexes, but quickly

78 reach lowland conditions (Lujan \& Armbruster, 2011).

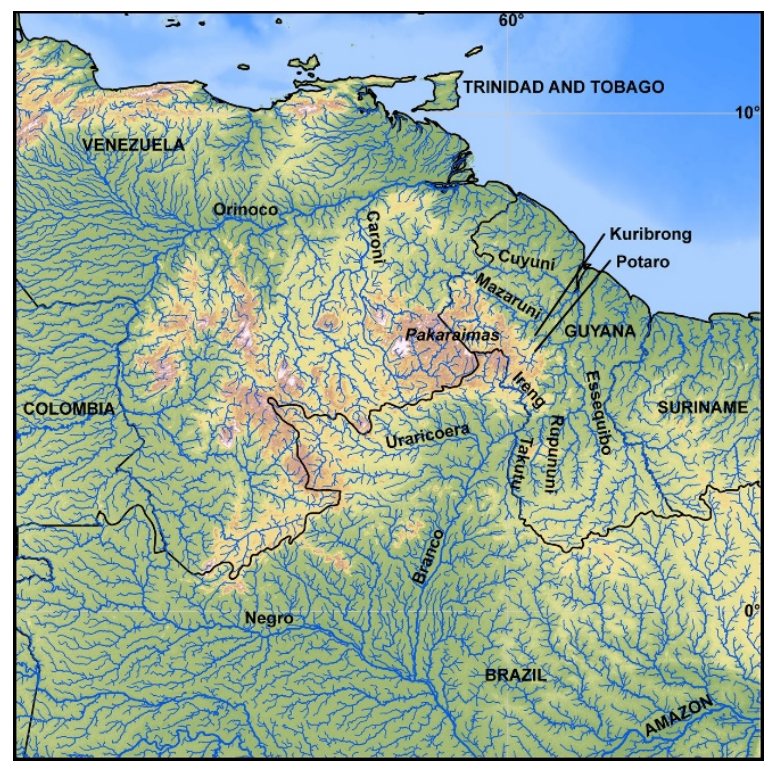

80 Figure 1. A topographical map of the Pakaraima highlands depicting the physiography of rivers.

81 Major rivers are labelled along their flow. Country names are listed horizontally in all capital

82 letters 
Current evidence for the relationships of the rivers draining the Pakaraima Mountains involves, in part, the development and subsequent fragmentation of a paleo-river drainage called the proto-Berbice (Lujan \& Armbruster, 2011; Schaefer \& do Vale, 1997; Sinha, 1968). The proto-Berbice contained what are now tributaries of the upper rio Branco (Amazon drainage, including the Ireng), the upper Essequibo, the Berbice, and parts of the Courantyne and Orinoco. Meanwhile, the middle and lower Essequibo (including the Potaro/Kuribrong) likely joined the Mazaruni and Cuyuni near where the current mouths are. Slowly, the Amazon River has been capturing streams from the proto-Berbice in an east-west manner. This pattern would suggest a similarity between the faunas of the Potaro/Kuribrong and the upper Mazaruni with the Ireng

93 being more distantly related as it appears to have never been connected into the middle and lower 94 Essequibo + Mazaruni.

However, the upper courses of the rivers have not been explored were suggested by the description of the crenuchid Apareiodon agmatos, and the loricariid taxa Paulasquama callis, Neblinichthys brevibraccium, and N. echinasus in the upper Mazaruni (Armbruster \& Taphorn, 2011; Taphorn, Armbruster, López-Fernández,

100 \& Bernard, 2010; Taphorn, López-Fernández, \& Bernard, 2008), all of which share

101 affinities with the Orinoco River basin. Given the absence of these taxa in lowland

102 streams, it is likely that these highland taxa were moving via stream capture or other

103 events that connected these highland tributaries. Thus far, the relationships of the

104 highland regions have been scarcely explored systematically. Lujan et al. (2018) found that Paralithoxus bovallii (Loricariidae) from the Ireng was more closely related to an undescribed species in the Courantyne than one from the lower Potaro in support of the

107 proto-Berbice hypothesis; however, Paralithoxus is not found elsewhere in the Pakaraima 108 highlands. Lujan et al. (in press) found that Corymbophanes (Loricariidae), an upper 109 Potaro/Kuribrong endemic, was sister to an undescribed genus from the upper Ireng with 110 the two clades separated by long branch lengths suggesting an ancient relationship.

111 Coupled with the lack of basic information on the fauna of the region, the area is 112 also under extreme threat by gold and diamond mining with a strong potential of mining 113 eliminating species before they are even discovered (Alofs et al., 2014). In this study, we 114 explore the potential interconnectedness of the high Pakaraima streams by examining the 
115 relationships of the pencil catfishes of the genus Trichomycterus in order to identify pertinent

116 diversity and to uncover biogeographic patterns that could be duplicated in other Pakaraima

117 organisms.

118 Trichomycteridae represents a diverse family of freshwater catfishes distributed across

119 the Neotropics. Of the more than 300 recognized species (Fricke, Eschmeyer, \& van der Laan,

120 2018), the majority of species (219) are found in the Trichomycterinae, which contains the

121 genera Bullockia, Cambeva, Eremophilus, Hatcheria, Ituglanis, Rhizosomichthys, Scleronema,

122 Silvinichthys, and Trichomycterus. Most of the diversity within Trichomycterinae can be

123 attributed to Trichomycterus, with all other genera except Ituglanis (28 species), Cambeva (25

124 species), Silvinichthys (seven species), and Scleronema (three species) being monotypic (Fricke

125 et al., 2018). While other genera exhibit apomorphic specializations, the lack of specializations

126 unique to Trichomycterus has long made researchers suspect, and later confirm with molecular

127 studies, the non-monophyly of the genus (Baskin, 2016; de Pinna, 2016; Henschel, Mattos, Katz,

128 \& Costa, 2018; Katz et al., 2018; Ochoa et al., 2017).

129 The emerging phylogenetic pattern matches those of other similarly distributed fishes,

130 such as doradid catfishes, characins, and armored catfishes, where distinct clades are

131 geographically linked to a Trans-andean/Amazonian distribution or to south Atlantic coastal

132 drainages (Katz et al., 2018; Ochoa et al., 2017; Ribeiro, 2006). Katz et al. (2018) attempted to

133 solve some of the taxonomic problems of the Trichomycterinae by restricting Trichomycterus to

134 a clade that contained the type species (south Atlantic coastal drainages), describing Cambeva

135 for a clade sister to Scleronema, a clade that is sister to Trichomycterus sensu stricto, and

136 referring the Andean, Pagaonian, Amazonian, and Guiana Shield species to "Trichomycterus" in

137 quotation marks. "Trichomycterus" is paraphyletic and part of a clade that includes Bullockia,

138 Eremophlius sensu stricto, and Ituglanis. Results were similar to those in Ochoa et al. (2017).

139 These patterns are not surprising, given the tectonic and geologic history of the continent that

140 highlights the importance of the Guiana and Brazilian Shields as original uplands of South

141 America, formation of the Andes, and uplift of the Eastern Cordillera (to name a few) with

142 shaping the biogeography of neotropical fishes (Lujan \& Armbruster, 2011; Lundberg et al.,

143 1998; Ribeiro, 2006). For ease, we will not be referring to Trichomycterus in quotation marks.

144 Trichomycterus are long, slender catfishes generally found only in swift waters. Such

145 habitat, even in the mountains, is patchy, and we suspect that the fishes would be more likely to 
146 be isolated to drainages. Recent collections from this region have identified all specimens

147 as T. guianensis (Eigenmann, 1912), but we noted significant differences in color and

148 morphology in samples that we have made. Preliminary external visual examinations

149 indicate the possibility for unrecognized diversity and perhaps misidentification of $T$.

150 guianensis in the rivers of this region. The only other species recognized in the region is

151 T. conradi (Eigenmann, 1912), and we have found some specimens from the Ireng and

152 Kuribrong rivers that correspond to this species.

153 Recent studies have illuminated the need to identify unrecognized diversity

154 within Trichomycterus and have highlighted the important role that geology and

155 topography play in contributing to that diversity (Katz et al., 2018; Ochoa et al., 2017;

156 Unmack, Bennin, Habit, Victoriano, \& Johnson, 2009). In this study, we 1) confirm the

157 discovery of multiple endemic Trichomycterus species in the region, 2) examine the

158 diversity and endemism of Trichomycterus in the Pakaraima Mountain region with

159 respect to the unique geologic features that have likely influenced their genetic structure,

160 and 3) provide clarification for the identification of T. guianensis and T. conradi based on

161 morphology.

162 METHODS

163 Taxon Sampling, DNA Extraction and Sequencing

164 Collections ranged across multiple years with research permits from Environmental

165 Protection Agency of Guyana as follows, listed as year, reference number: 2011, 030510 BR

166 130; 2008, 300408 SP: 004; 2014, 040414 SP: 003; 2015, 123115 BR031; 2016, 012016 SP:

167 003. Fish were either collected with six-foot by ten-foot nylon coated seines with $1 / 8$ " mesh, or

168 we joined fishing expeditions of the Patamona who used hiari, a root native to the area around

169 the collection site and a natural source of rotenone (Figure 2). After capture, fish were

170 euthanized in a solution of tricaine methanesulfonate (MS-222) until no sign of respiration was

171 observed for five minutes. Tissue samples were taken from the right pectoral fin or right axial

172 musculature and placed into $1.5 \mathrm{~mL}$ vials containing RNALater or ethanol for preservation. Once

173 tissue samples were taken, voucher specimens were fixed in a 3.7\% formaldehyde solution for

174 seven days, then rinsed in water for three days, and finally stored in $70 \%$ ethanol. Vouchers and 

the authors were requested from the Royal Ontario Museum (ROM, Table 1).

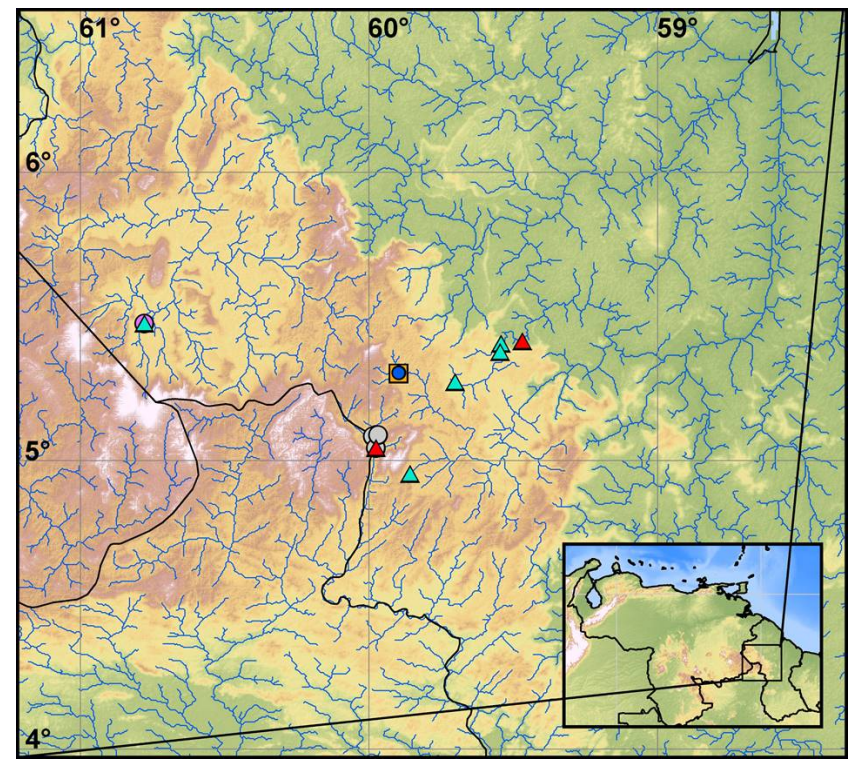

178 Figure 2. Collection localities for species of Trichomycterus found in this study. Color codes correspond to images in Figure 7 and are as follows: red triangles, $T$. conradi; blue circle, $T$.

180 guianensis; teal triangles, T. cf. guianensis; purple circle, Mazaruni, plain form; orange square, Potaro elongate; gray circle, Ireng, spotted form.

Whole genomic DNA was extracted from tissues using either Chelex or an E.Z.N.A

184 Tissue DNA Kit (Omega BioTek, Norcross, GA). The four genes 16S, COI, cytb, and RAG2

185 were amplified through $25 \mu \mathrm{L}$ polymerase chain reactions using primers described in Ochoa et al.

186 (2017). The 16S gene was amplified using the following protocol: initial denaturation step of 180

$187 \mathrm{~s}$ at $94^{\circ} \mathrm{C}$ then 30 cycles of denaturation $\left(45 \mathrm{~s}\right.$ at $\left.95^{\circ} \mathrm{C}\right)$, annealing $\left(30 \mathrm{~s}\right.$ at $\left.54^{\circ} \mathrm{C}\right)$, and extension

$188\left(60 \mathrm{~s}\right.$ at $\left.68^{\circ} \mathrm{C}\right)$ followed by a final extension of $600 \mathrm{~s}$ at $68^{\circ} \mathrm{C}$. The $\mathrm{COI}$ gene was amplified using

189 the following protocol: initial denaturation step of $180 \mathrm{~s}$ at $94^{\circ} \mathrm{C}$ then 30 cycles of denaturation

$190\left(45 \mathrm{~s}\right.$ at $\left.94^{\circ} \mathrm{C}\right)$, annealing $\left(30 \mathrm{~s}\right.$ at $\left.54^{\circ} \mathrm{C}\right)$, and extension $\left(60 \mathrm{~s}\right.$ at $\left.68^{\circ} \mathrm{C}\right)$ followed by a final

191 extension of $60 \mathrm{~s}$ at $68^{\circ} \mathrm{C}$. The cytb gene was amplified using the following protocol: initial

192 denaturation step of $180 \mathrm{~s}$ at $94^{\circ} \mathrm{C}$ then 30 cycles of denaturation $\left(45 \mathrm{~s}\right.$ at $\left.95^{\circ} \mathrm{C}\right)$, annealing $(30 \mathrm{~s}$

193 at $\left.54^{\circ} \mathrm{C}\right)$, and extension $\left(60 \mathrm{~s}\right.$ at $\left.68^{\circ} \mathrm{C}\right)$ followed by a final extension of $60 \mathrm{~s}$ at $68^{\circ} \mathrm{C}$. The RAG2

194 gene was amplified using a two-step protocol. The first reaction was performed using the

195 touchdown protocol described in Lovejoy \& Collette (2001) with RAG164F and RAG2R6

196 primers. The second PCR used $1.5 \mu \mathrm{L}$ of template from the first run and primers $176 \mathrm{R}$ and

197 RAG2Ri under the following conditions: initial denaturation step of $30 \mathrm{~s}$ at $95^{\circ} \mathrm{C}$ then 35 cycles 
of denaturation $\left(30 \mathrm{~s}\right.$ at $\left.95^{\circ} \mathrm{C}\right)$, annealing $\left(45 \mathrm{~s}\right.$ at $\left.56^{\circ} \mathrm{C}\right)$, and extension $\left(90 \mathrm{~s}\right.$ at $\left.72^{\circ} \mathrm{C}\right)$.

199 Primers used for PCR amplification were also used for DNA sequencing for all genes, with 176R and RAG2Ri used for sequencing RAG2.

The products were visualized and size-verified on a $0.8 \%$ agarose gel. PCR purification, sample preparation, and Sanger sequencing were performed at GeneWiz

203 (South Plainfield, NJ). Chromatographs from forward and reverse reads were imported

204 into Geneious v. 10.2.3 (Kearse et al., 2012) for assembly. Assembled contiguous

205 sequences were aligned using the MUSCLE algorithm (Edgar, 2004), and results were

206 checked by eye. Due to length variation among sequences generated in this study and

207 those of Ochoa et al (2017), alignments were trimmed to the following lengths: 16S: 466;

208 COI 522; cytb: 858; myh6: 543; and RAG2: 885. Each individual gene tree was analyzed

209 with Scleronema minutum as an outgroup, while the concatenated dataset $(3579 \mathrm{bp})$

210 included members from Ochoa et al's (2017) clades D1, D2, D3, and E with S. minutum

211 as an outgroup. Data were exported both as individual alignments and as a concatenated

212 dataset for phylogenetic analysis.

214 Phylogenetic Analysis

215 Best-fit models of evolution were tested using PARTITIONFINDER2 (Lanfear, Frandsen,

216 Wright, Senfeld, \& Calcott, 2017). Models were tested on individual gene trees, and then on the 217 concatenated dataset. The resulting data blocks were then used in Bayesian Inference analysis.

218 Bayesian Inference was performed using MrBayes v. 3.2.6 on XSEDE via CIPRES Science

219 Gateway (Miller, Pfeiffer, \& Schwartz, 2010). Each dataset had 2 runs with 4 chains run for 15

220 million generations, sampling once every 1,000 generations. The parameters and trees were

221 summed in MrBayes v. 3.2.6 using the default 25\% burn-in. The resulting 50\% majority

222 consensus rule phylogeny is reported.

224 Maps

225 The maps produced for this paper were created in ARCGIS, ARCMAP V. 10.3.1; ESRI, 2011).

226 Digital elevation models and rivers are from HydroSHEDS by the United States Geological

227 Service and World Wildlife Federation (https://www.worldwildlife.org/pages/hydrosheds;

228 https://hydrosheds.cr.usgs.gov/). Width of rivers is by Strahler number (stream order). 
Bathymetry is ETOPO1 from the National Geophysical Data Center

230 (https://www.ngdc.noaa.gov/mgg/global/). Color ramps for elevation and bathymetry are from

231 Environmental Systems Research Institute's Color Ramps v. 3.0 (https://www.esri.com/arcgis-

$232 \mathrm{blog} /$ products/product/imagery/esri-color-ramps-version-3-0/). Country borders and graticules

233 are from Natural Earth (https://www.naturalearthdata.com/).

\section{RESULTS}

Four genes trees were analyzed separately, then combined into a concatenated analysis.

237 The first individual gene tree is cytochrome b (cytb, Figure 3), which results in a well-supported

238 clade of Pakaraima Trichomycterus. Members of true Trichomycterus guianensis are found sister

239 to the Potaro, elongate form. This clade is sister to another well-supported clade of $T$. $c f$.

240 guianensis + Mazaruni, plain form. These are all sister to a single representative of the $T$.

241 conradi. This analysis did not include the Ireng, spotted form that is present in other analyses.

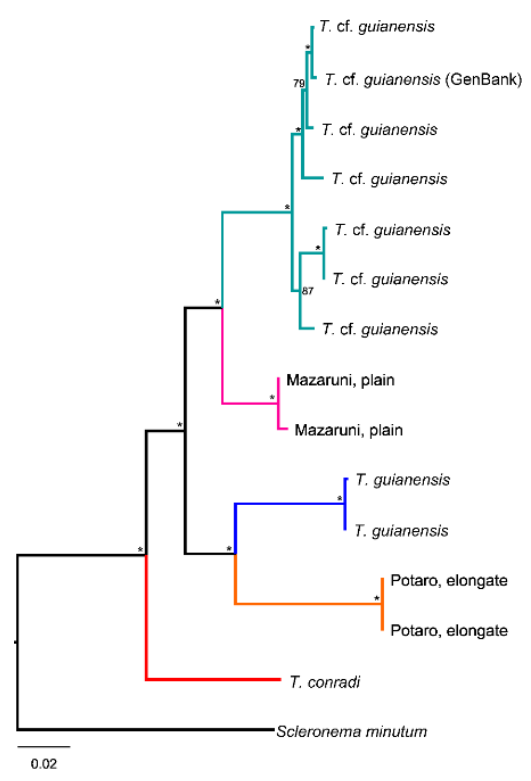

Figure 3. Fifty per cent majority rule consensus tree from Bayesian inference of cytochrome $b$ sequences. Nodes labelled with an asterisk (*) indicate posterior probabilities $>90 \%$. Values less than $90 \%$ are written on the trees. Branches are colored to match localities as seen in Figure 1. Tip labels correspond to individuals as denoted in Table 1.

The second gene tree generated from our data is based on COI (Figure 4). This analysis 250 again places T. $c f$. guianensis sister to the Mazaruni, plain form. In contrast to the cytb 251 phylogeny, this clade is sister to the T. conradi; however, this relationship is weakly supported. 
252 The (T. cf. guianensis + Mazaruni, plain) T. conradi clade is sister to another clade

253 consisting of the Ireng, spotted form and true T. guianensis. The interrelationships among

254 the clades are poorly supported, but each recognized morphotype is well-supported with

255 the exception of the Ireng, spotted form. Finally, the Potaro, elongate form is missing

256 from this analysis. Overall, the COI tree is much less resolved than the other trees, with

257 some nodes not reaching $90 \%$ posterior probability.

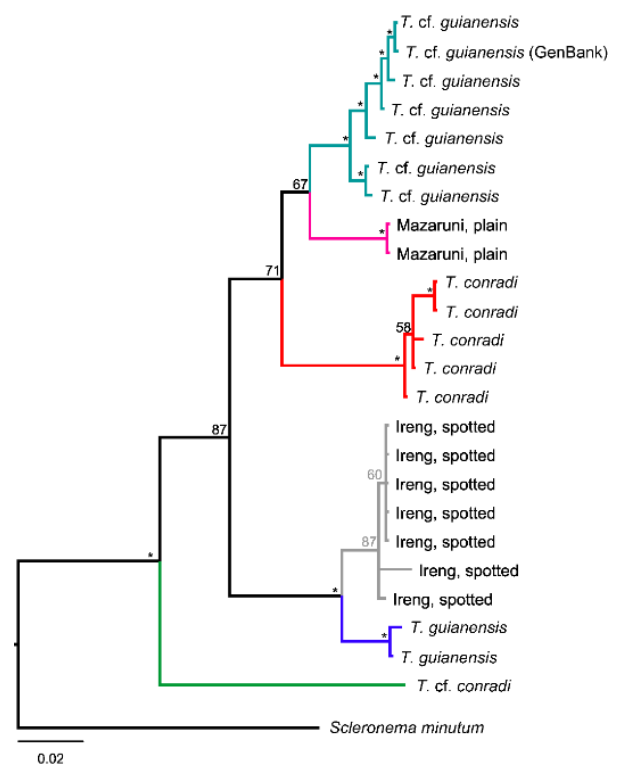

Figure 4. Fifty per cent majority rule consensus tree from Bayesian inference of COI sequences. Nodes labelled with an asterisk (*) indicate posterior probabilities $>90 \%$. Values less than $90 \%$ are written on the trees. Branches are colored to match localities as seen in Figure 1. Tip labels correspond to individuals as denoted in Table 1.

Ribosomal 16s data place T. $c f$. guianensis sister to the Mazaruni, plain form (Figure 5). This clade is sister the T. conradi. As seen in the COI analysis, despite geographic proximity, the 266 Ireng, spotted form is sister to true T. guianensis rather than the T. conradi. The Potaro, elongate 267 form is sister to the rest of the member clade.

Nuclear DNA analysis from the RAG2 data was the most divergent from the

269 remainder of the data (Figure 6). Again, T. cf. guianensis is recovered sister to the

270 Mazaruni, plain form, but this is the only similarity with the other gene trees. The RAG2

271 data show true T. guianensis sister to the Ireng, spotted form. They form a clade sister to

272 the Potaro, elongate form. The T. conradi is paraphyletic and its relationships are

273 unresolved due to a polytomy. 


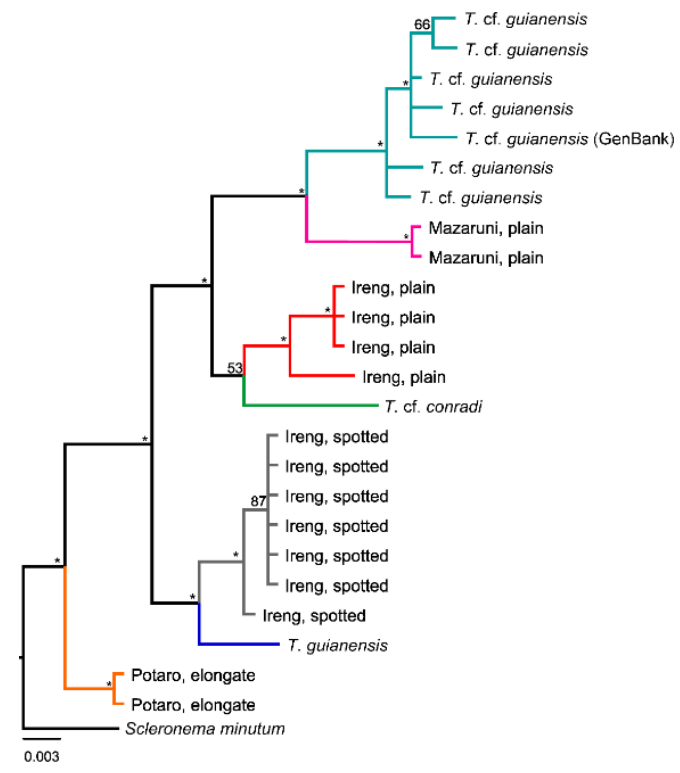

Figure 5. Fifty per cent majority rule consensus tree from Bayesian inference of $16 \mathrm{~S}$ sequences. Nodes labelled with an asterisk (*) indicate posterior probabilities $>90 \%$. Values less than $90 \%$ are written on the trees. Branches are colored to match localities as seen in Figure 1. Tip labels correspond to individuals as denoted in Table 1.

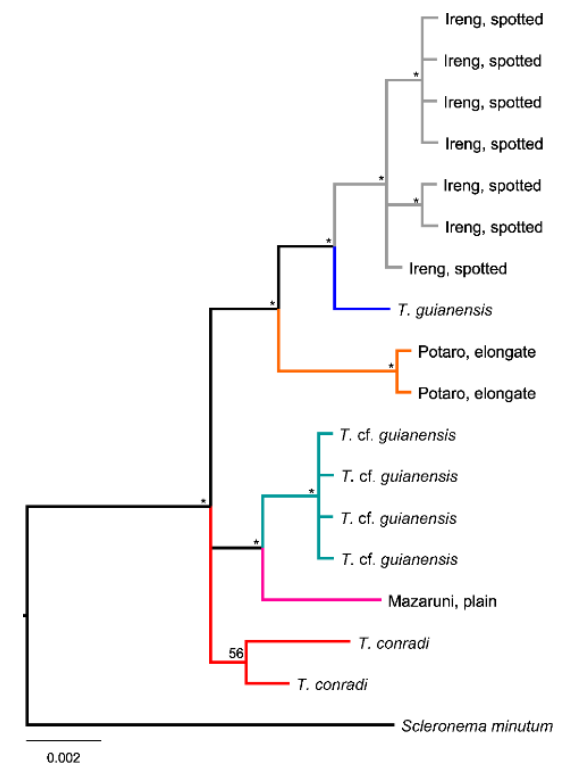

Figure 6. Fifty per cent majority rule consensus tree from Bayesian inference of RAG2 sequences. Nodes labelled with an asterisk $(*)$ indicate posterior probabilities $>90 \%$. Values less than $90 \%$ are written on the trees. Branches are colored to match localities as seen in Figure 1. Tip labels correspond to individuals as denoted in Table 1. and analyzed with the D1, D2, D3, and E clades from Ochoa et al (2017, Figure 7). This tree, 
with 24 individuals from our analysis, shows that all morphotypes we identified a priori are monophyletic. Two distinct clades compose Pakaraima Trichomycterus:

290 Trichomycterus $c f$. guianensis + Mazaruni, plain form are sister to the T. conradi. This

291 clade is sister to another clade consisting of Trichomycterus guianensis + Ireng, spotted

292 which are sister to the Potaro, elongate form. Each of these relationships are supported

293 with $>90 \%$ posterior probability, while deeper relationships remain unresolved.
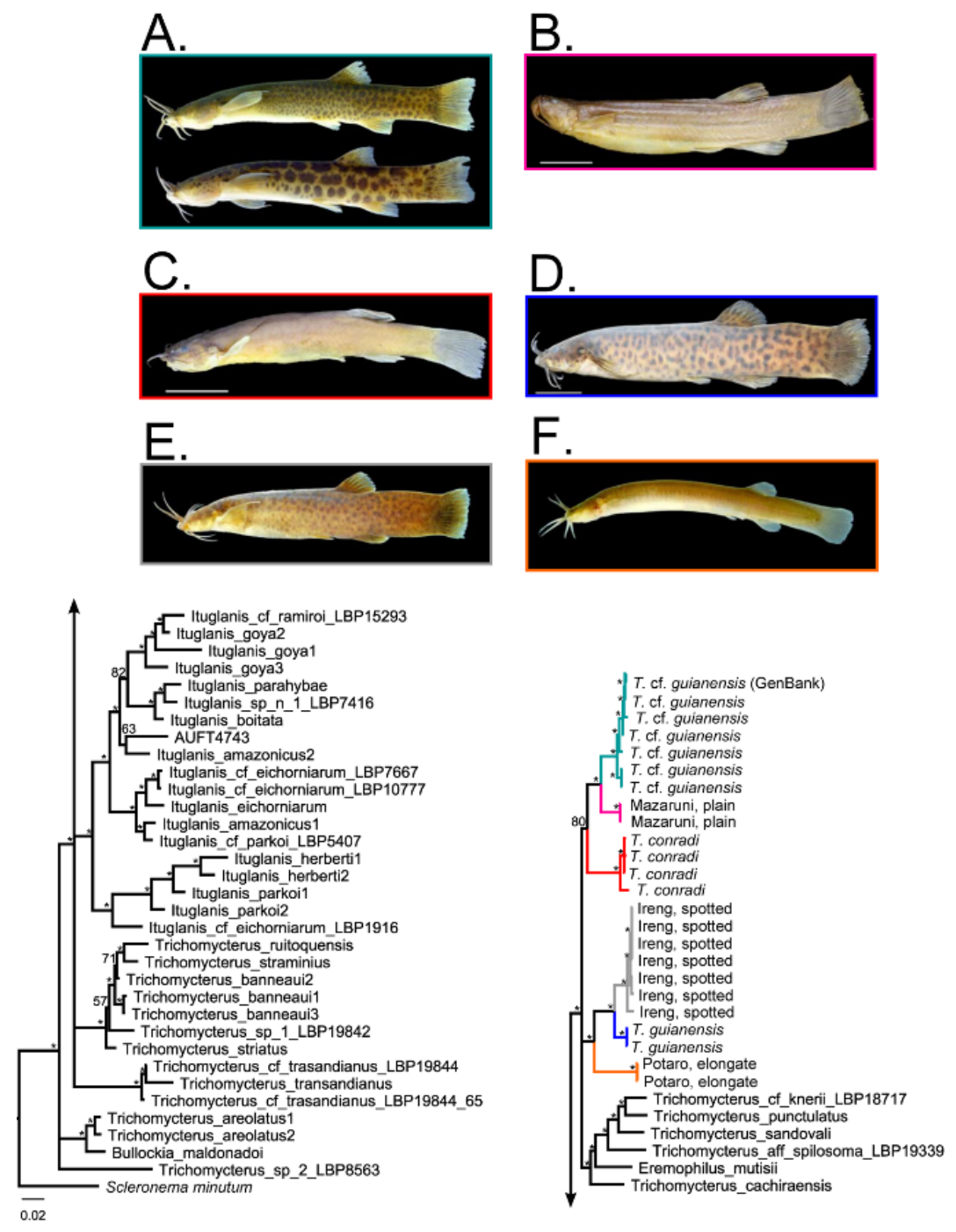

295 Figure 7. Fifty per cent majority rule consensus tree from Bayesian inference of concatenated sequences. Nodes labelled with an asterisk (*) indicate posterior probabilities $>90 \%$. Values less than $90 \%$ are written on the trees. Branches are colored to match localities as seen in Figure 1. Tip labels correspond to individuals as denoted in Table 1. These sequences are combined with the D1, D2, D3, and E clades from Ochoa et al (2017). Arrows connect disconnected branches in the phylogeny. Outlines of the photographs of specimens correspond to clade color and symbol color in Figure 1. A. T. cf. guianensis. B. Mazaruni, plain form. C. T. conradi. D. true $T$. guianensis. E. Ireng, spotted form. F. Potaro, elongate form. 


\section{DISCUSSION}

Our results demonstrate the presence of multiple species of Trichomycterus in the Pakaraima Mountains of Guyana. There were two major clades, one consisting of T. guianensis and two undescribed species, and the other of $T$. conradi and two undescribed species. Both $T$. guianensis and T. conradi appear to be the rarer species in the region (based on collections), and T. guianensis is not as widespread as previously believed. Based on examination of the types and comparison with specimens we have collected, Trichomycterus guianensis is a deep bodied species with irregular blotches (Figure 7D). Trichomycterus sp. Ireng Spotted (Figure 7E) is the

311 dominant species in the Ireng, and it is similar in morphology to T. guianensis and was recovered

312 as sister to it. In morphology, the Ireng Spotted species is even shorter and deeper-bodied than $T$.

313 guianensis. Sister to the clade of T. guianensis and the Ireng Spotted species is a very elongate,

314 almost entirely brown species from near Ayangana in the far upper Potaro with miniscule pelvic

315 fins (Trichomycterus sp. Potaro Elongate, Figure 7F). It was found in sluggish, swampy areas,

316 which is habitat more indicative of Ituglanis, but the species lacks the diagnostic characters of

317 Ituglanis (JWA pers. obs.), and we found it to be a member of Trichomycterus in the molecular

318 analysis. Trichomycterus sp. Potaro Elongate and Trichomycterus sp. Ireng Spotted are at the

319 opposite extreme of Trichomycterus morphology, suggesting a strong capacity for body

320 rearrangement in the genus.

321 The other major clade contains a wide-spread, elongate species with dark, small or large,

322 regular spots (Trichomycterus cf. guianensis, Figure 7A). This species is found in the upper

323 Potaro, Kuribrong, and Mazaruni rivers. Little geographic structure was present in the specimens

324 examined, suggesting fairly recent movement between the basins. Sister to this species is a

325 similar but unspotted species from the Mazaruni River (Trichomycterus sp. Mazaruni Plain,

326 Figure 7B). Finally, sister to the other two species is a clade that consists of a few individuals

327 from the Ireng as well as a specimen from the lower Kuribrong of a plain-colored species that

328 appears to be $T$. conradi (Figure 7C).

329 Two species of Trichomycterus have been described from the upper Caroni, Orinoco

330 River drainage section of the Pakaraima Mountains: T. celsae Lasso and Provenzano 2002 and T.

331 lewi Lasso and Provenzano 2002. The Orinoco species do appear to be different from the species

332 analyzed here, and it appears that there are additional undescribed species from that region.

333 Unfortunately, we do not have tissue samples from these species. 


\section{Biogeography of the Pakaraima Mountains}

The biogeographic story that the species of Trichomycterus of the Pakaraimas tell is a complex one. Trichomycterus cf. guianensis appears to have moved between river systems relatively easily. Mazaruni samples are sister to those in the Kuribrong and Potaro rivers, but the Mazaruni samples are paraphyletic. Tributaries of the Mazaruni interdigitate with the Kuribrong and Potaro rivers, and species living as high in their drainages as Trichomycterus would be more likely to be able to move via river capture events where tributaries erode their divides and switch from one system to the next. Anecdotal reports suggest that the upper courses of at least the Potaro and Kuribrong connect during particularly rainy times; flying over the area reveals numerous fissures that seem to run between the two rivers (JWA pers. obs.). These drainages also interdigitate with Caroni and Ireng tributaries. Some of the specimens from the Caroni do appear similar to the elongate, spotted species of Guyana, but we did not find anything similar in the Ireng despite extensive searching.

The upper Caroni and the Ireng were once part of the proto-Berbice paleodrainage basin along with the upper Branco, upper Essequibo, Berbice, and Courantyne rivers while the Mazaruni was likely independent (Lujan and Armbruster, 2011). The Essequibo makes a westward bend near Massara and away from a nearby Berbice tributary (Gibbs \& Barron, 1993),

352 suggesting a likely point of demarcation between the upper Essequibo as part of the proto-

353 Berbice and the lower Essequibo, which probably joined with the Mazaruni at the present mouth

354 of the Essequibo. This would mean that the Potaro and Mazaruni were part of the same system

355 and not part of the proto-Berbice. However, the mixing of Ireng, Potaro, and Mazaruni

356 Trichomycterus in the phylogeny suggests that there likely existed faunal exchange between the

357 proto-Berbice, Potaro, and Mazaruni rivers at least in the highlands prior to the breakup of the

358 proto-Berbice during the Pliocene and Pleistocene potentially leading to complex

359 interrelationships between these basins. A similar finding was made in Lujan et al. (in press) who

360 found that Corymbophanes was sister to a new genus from the Ireng; however, the branch

361 lengths were much longer than what was observed here. Further exploration into the

362 relationships of Trichomycterus along with a molecular clock will likely lead to fascinating

363 insights into the biogeography of the Pakaraima Mountains, but this further insight will require 
extensive collecting in the difficult to explore Brazilian tributaries of the Pakaraima Mountains and further collecting in Venezuela, that is difficult now because of civil strife. Kaieteur and Amaila Falls on the Potaro and Kuribrong, respectively, as well as in the Ireng. The shallow nodes between the Kuribrong and Ireng samples sequenced suggest that movement has been relatively recent. We were only able to obtain $16 \mathrm{~S}$ sequences for a specimen of $T$. $c f$. conradi from the Maroni River of eastern Suriname, and it was sister to T. conradi. A similar distribution across the northern Guiana Shield was found for Paralithoxus bovallii from the Ireng River and hypothesized new species related to it in the Potaro, Courantyne, and Coppename rivers (Lujan et al. 2018). The distributions of T. conradi and P. bovallii sensu lato suggest interconnectivity across the Guiana Shield even for small fishes restricted to fast-flowing streams. Clearly, we are just beginning to understand the complexities of the biogeography of the western Guiana Shield and the interconnectedness of it with the eastern portion of the shield.

\section{Threats to Biodiversity in the Guyana Highlands}

The Pakaraimas represent the cores of ancient mountains, which are among the main sources of gold and diamonds. Alofs et al. (2014) review some of the issues with gold mining in the upper Mazaruni River, and we have observed similar issues in the Kuribrong and Potaro Rivers as well. Large swaths of forest have been removed from around the rivers with the sediment pumped through sieves to extract gold and diamonds. Gold is removed with mercury amalgamation leading to high mercury levels in the water, fishes, and humans (Miller et al. 2003) and large swaths of forest replaced by denuded landscapes and toxic spoil ponds. On

386 larger rivers like the lower Potaro, large dredging machines suck up sediment and process it 387 directly in the river leaving behind piles of gravel in the river that alter the natural hydrology.

388 Although Hardman et al. (2002) did not find significant differences between their study of the 389 fishes of the Potaro River and Eigenmann (1912), certain species that had been present and 390 common in Eigenmann's survey were absent 90 years later. Mol \& Ouboter (2004) and Brosse,

391 Grenouillet, Gevrey, Khazraie, \& Tudesque (2011) found that the erosion related to gold mining 392 has reduced fish diversity. As of our 2014 trip to the upper Kuribrong and 2016 trip to the Ireng, 393 there was little impact to the rivers from mining; however, a recently completed road now 394 provides easier access to the upper Kuribrong, and one small mine was observed. The lower 
395 Kuribrong has been heavily impacted, and after flying over the Potaro River in 2014, JWA can

396 state that the Potaro looks less clear than it had during the 1998 expedition reported in Hardman

397 et al. (2002).

As expressed by Alofs et al. (2014) for the upper Mazaruni, the whole high plateau of the

Pakaraimas supports an endemic fauna as is evidenced here. Although there is some interconnectivity of the river systems, narrow endemic Trichomycterus are found in each of the rivers in this study. Conservation of this unique landscape that has become part of our shared cultural heritage is important, and further studies on the unique fauna of the region are needed.

\section{REFERENCES}

Alofs, K. M., Liverpool, E. A., Taphorn, D. C., \& Bernard, R. (2014). Mind the (information) gap: the importance of exploration and discovery for assessing conservation priorities for freshwater fish, 107-113. https://doi.org/10.1111/ddi.12127

Armbruster, J. W., \& Taphorn, D. C. (2011). A New Genus and Species of Weakly Armored Catfish from the Upper Mazaruni River, Guyana (Siluriformes: Loricariidae), (1), 46-52. https://doi.org/10.1643/CI-08-187

Baskin, J. N. (2016). Structure and relationships of the Trichomycteridae (first edition of the original thesis presented in 1973)*. Neotropical Ichthyology (Vol. 14). https://doi.org/10.1590/1982-0224-20150127

Brosse, S., Grenouillet, G., Gevrey, M., Khazraie, K., \& Tudesque, L. (2011). Small-scale gold mining erodes fish assemblage structure in small neotropical streams. Biodiversity and

423 Doyle, A. C. (1912). The Lost World. Hodder \& Stoughton.

424 Edgar, R. C. (2004). MUSCLE : multiple sequence alignment with high accuracy and high throughput, 32(5), 1792-1797. https://doi.org/10.1093/nar/gkh340 
Fricke, R., Eschmeyer, W. N., \& van der Laan, R. (2018). Catalog of Fishes: Genera, species, references. Retrieved September 24, 2018, from

Gibbs, A., \& Barron, C. (1993). The Geology of the Guiana Shield. Oxford: Oxford University Press.

Hardman, M., Page, L. M., Sabaj, M. H., Armbruster, J. W., \& Knouft, J. H. (2002). A comparison of fish surveys made in 1908 and 1998 of the Potaro, Essequibo, Demerara, and coastal river drainages of Guyana, 13(3), 225-238.

Henschel, E., Mattos, J. L. O., Katz, A. M., \& Costa, W. J. E. M. (2018). Position of enigmatic miniature trichomycterid catfishes inferred from molecular data (Siluriformes). Zoologica Scripta, 47(1), 44-53. https://doi.org/10.1111/zsc.12260

Katz, A. M., Barbosa, M. A., Leonardo, J., Mattos, D. O., Eduardo, W. J., Costa, M., \& Bartsch,

Kearse, M., Moir, R., Wilson, A., Stones-Havas, S., Cheung, M., Sturrock, S., ... Drummond, A. P. (2018). Multigene analysis of the catfish genus Trichomycterus and description of a new South American trichomycterine genus ( Siluriformes , Trichomycteridae ), 94(2), 557-566.

Lovejoy, N. R., \& Collette, B. B. (2001). Phylogenetic Relationships of New World

Lujan, N. K., \& Armbruster, J. W. (2011). The Guiana Shield. In J. A. Albert \& R. E. Reis (Eds.), Historical Biogeography of Netropical Freshwater Fishes (pp. 211-225). University of California Press. https://doi.org/10.1525/california/9780520268685.003.0013 
south american rivers. Phylogeny and Classification of Neotropical Fishes, (January), 603.

Miller, M. A., Pfeiffer, W., \& Schwartz, T. (2010). Creating the CIPRES Science Gateway for inference of large phylogenetic trees. 2010 Gateway Computing Environments Workshop, GCE 2010. https://doi.org/10.1109/GCE.2010.5676129

Mol, J. A. N. H., \& Ouboter, P. E. (2004). Downstream Effects of Erosion from Small-Scale Gold Mining on the Instream Habitat and Fish Community of a Small Neotropical Rainforest Stream, 18(1), 201-214.

Ochoa, L. E., Roxo, F. F., DoNascimiento, C., Sabaj, M. H., Datovo, A., Alfaro, M., \& Oliveira, C. (2017). Multilocus analysis of the catfish family Trichomycteridae (Teleostei: Ostariophysi: Siluriformes) supporting a monophyletic Trichomycterinae. Molecular Phylogenetics and Evolution, 115(July), 71-81. https://doi.org/10.1016/j.ympev.2017.07.007

Ribeiro, A. C. (2006). Tectonic history and the biogeography of the freshwater fishes from the coastal drainages of eastern Brazil: An example of faunal evolution associated with a divergent continental margin. Neotropical Ichthyology, 4(2), 225-246. https://doi.org/10.1590/S1679-62252006000200009

Schaefer, C. E. R., \& do Vale, J. F. J. (1997). Mudanças climáticas e evolução da paisagem em Roraima: uma resenha do Cretáceo ao Recente. In R. I. Barbosa, E. J. G. Ferreira, \& E. G. Castellón (Eds.), Homem, Ambiente e Ecologia na Estado de Roraima (pp. 231-265). Manaus, Brazil: INPA.

Sinha, N. K. P. (1968). Geomorphic evolution of the Northern Rupununi Basin, Guyana. McGill

Taphorn, D. C., López-Fernández, H., \& Bernard, C. R. (2008). Apareiodon agmatos, a new species from the upper Mazaruni river, Guyana (Teleostei: Characiformes: Parodontidae). Zootaxa, 1925, 31-38. https://doi.org/10.5281/zenodo.184772

Unmack, P. J., Bennin, A. P., Habit, E. M., Victoriano, P. F., \& Johnson, J. B. (2009). Impact of 
ocean barriers, topography, and glaciation on the phylogeography of the catfish

\section{DATA ACCESSIBILITY STATEMENT}

494 Sequence data are available on GenBank. Accession numbers for each specimen and gene are 495 listed in Table 1.

496 Note: Accession numbers will be included upon acceptance of the paper.

498 TABLES (each table complete with title and footnotes)

499 Table 1. Collection information for Trichomycterus species used in this study. GenBank

$500 \quad$ Accession numbers are provided for each gene and individual. 

aCC-BY-NC-ND 4.0 International license.

\begin{tabular}{|c|c|c|c|c|c|c|c|}
\hline Tissue Catalog & Species ID & Voucher Number & Latitude & Longitude $\quad 16 \mathrm{~S}$ & COI & Cytb & RAG2 \\
\hline AUFT10166 & Ireng, spotted & 67129 & 5.08955 & -59.97514 Y & Y & Y & $Y$ \\
\hline AUFT10168 & Ireng, spotted & 67129 & 5.08955 & $-59.97514 \mathrm{Y}$ & $\mathrm{Y}$ & - & Y \\
\hline AUFT10169 & Ireng, spotted & 67129 & 5.08955 & $-59.97514 Y$ & Y & $\mathrm{Y}$ & $\mathrm{Y}$ \\
\hline AUFT10170 & Ireng, spotted & 67129 & 5.08955 & $-59.97514 Y$ & Y & Y & Y \\
\hline AUFT10212 & T. conradi & 67138 & 5.04398 & $-59.97717 Y$ & Y & Y & Y \\
\hline AUFT10213 & T. conradi & 67138 & 5.04398 & $-59.97717 Y$ & Y & Y & - \\
\hline AUFT10234 & Ireng, spotted & 67154 & 5.08388 & $-59.98762 Y$ & Y & $\mathrm{Y}$ & Y \\
\hline AUFT10276 & Ireng, spotted & 67179 & 5.04398 & $-59.97717 \mathrm{Y}$ & Y & - & Y \\
\hline AUFT10294 & T. conradi & 67194 & 5.08867 & $-59.96952 Y$ & Y & Y & - \\
\hline AUFT10310 & Ireng, spotted & 67172 & 5.08955 & $-59.97514 Y$ & Y & Y & Y \\
\hline AUFT2110 & T. guianensis & 63677 & 5.30181 & $-59.89838 Y$ & Y & - & - \\
\hline AUFT2186 & T. cf. guianensis & 62902 & 5.40532 & $-59.5439 Y$ & Y & - & Y \\
\hline AUFT4743 & T. cf. conradi & 51758 & 4.767118 & $-54.56462 Y$ & Y & Y & - \\
\hline AUFT6563 & T. guianensis & 62932 & 5.30181 & $-59.89838-$ & Y & - & Y \\
\hline AUFT6596 & Potaro, elongate & 62949 & 5.304 & $-59.89819 Y$ & - & - & Y \\
\hline AUFT6597 & Potaro, elongate & 62949 & 5.304 & $-59.89819 Y$ & - & - & Y \\
\hline ROMT06183 & Mazaruni, plain & 83791 & 5.4755 & $-60.77967 Y$ & Y & Y & Y \\
\hline ROMT06184 & Mazaruni, plain & 83791 & 5.4755 & $-60.77967 Y$ & Y & Y & - \\
\hline ROMT06185 & T. cf. guianensis & 83790 & 5.4755 & $-60.77967 \mathrm{Y}$ & Y & Y & - \\
\hline ROMT06186 & T. cf. guianensis & 83790 & 5.4755 & $-60.77967 \mathrm{Y}$ & Y & Y & - \\
\hline ROMT12696 & T. cf. guianensis & 89932 & 4.95407 & $-59.85882 Y$ & Y & Y & Y \\
\hline ROMT15527 & T. cf. guianensis & 91392 & 5.272085861 & $-59.7026908 Y$ & Y & Y & Y \\
\hline ROMT15575 & T. cf. guianensis & 91500 & 5.3759978 & $-59.5472803 Y$ & Y & Y & Y \\
\hline ROMT15595 & T. conradi & 91436 & 5.413958782 & $-59.470252 \mathrm{Y}$ & Y & Y & Y \\
\hline
\end{tabular}

